\title{
Relationship Between Governance and Development: Lessons of the Southeast Asian Nations
}

\author{
Huu Quyet Nguyen \\ Vinh Univerity, Vinh City, Nghe An, Vietnam
}

\begin{abstract}
This paper attempts to examine the relationship between governance and development in the state-building process. It argues that political leadership — authoritarianism — is the first and decisive element to bring about economic development before promoting democracy in the Southeast Asian developing countries. Unlike Western-style democratic governance which attaches importance to a democracy-based development strategy, the "economic development first, democracy later" approach to create social and political stability required for economic development proved rational and successful in the state-building of the Southeast Asian region where there is a vast diversity and where a majority of population still lives under the trap of poverty. Not until economic growth is attained, should a transitory period to the sluggish pace of promoting democracy coupled with development of governance institutions be required, otherwise it is likely to drive the governance into collapse. This is a question of good governance in Southeast Asia which provides an illuminating context to examine the region's governmental performances that sharply differ from those in Europe.
\end{abstract}

Keywords: Southeast Asia, state building, development, democracy

The relationship between governance and development has risen up the international policy debate, particularly when problems of governance are at the center of many of the urgent challenges confronting developing countries. In the development process, each nation's path to good governance is different, depending on culture, geography, political and administrative transitions, economic conditions, and many other factors (Al-jurf, 2010, p. 1). Southeast Asia is the region with the vast diversities in cultures, languages, religions, economic backgrounds, and ethnicities, thus implications for governance required for development are different from Western-style democratic governance. In other words, such a developing world as Southeast Asia cannot start with the Western democratic model, because, as argued by Weatherbee (2004, pp. 180-181), good governance is demonstrated when, in the context of a state's particular political, social, cultural, and economic situation - its uniqueness - the governing authority formulates and implements (to the degree possible) public policy clearly designed to achieve these goals.

This paper is aimed to analyze the governance and development relationship in which it argues that political leadership - authoritarianism - is the first and decisive element to bring about economic development before promoting democracy. In other words, "economic development first, democracy later" approach to create social and political stability required for economic development is of the greatest importance to

Corresponding author: Huu Quyet Nguyen, Ph.D. in international relations, lecturer of political sciences, Vinh University, Vinh City, Nghe An, Vietnam; research fields: international relations in East Asia, the South China Sea disputes, and Vietnam's contemporary foreign policy. 
Southeast Asian developing countries, where there is vast diversity and where a majority of population still lives under the trap of poverty. In this respect, the experience and lessons of authoritarian governance in the development process of some Southeast Asian member countries will be examined to support the argument. Before analyzing the governance-development relationship, it is necessary to define governance and development, which are varyingly viewed by scholars.

\section{Defining Governance}

According to a 1991 World Bank report, governance is defined as "the manner in which power is exercised in the management of a country's economic and social resources for development" (Al-jurf, 2010, p. 2). Instrumentally defined, governance is made up of aggregated elements including: political leadership, bureaucratic capacity, representation and accountability, transparency and non-corrupt judiciary enforcing the rule of law, and participation. The former definition is general and implicit while the latter is specification of the former, but seems rather comprehensive and logic. The author strongly agrees on the latter definition by adding that "Economic governance - sound development management-is at the core of sustainable development" (Asian Development Bank, 1999, p. 16). Also, good governance is the management in the process of development and the keys to good governance are leadership's political will and political capacity.

\section{Defining Development}

Development is the process of bringing about fundamental and substantial changes in the society. It encompasses and embraces such aspects of the equality of life as social justice, equality of opportunity for all citizens, equitable distribution of income, and democratization in the development process. Thus, "Development involves not only capital accumulation and economic growth but also the condition in which a country has adequate food and job and the income inequality among them is greatly reduced" (Lawal \& Tobi, 2006, p. 644). In other words, macroeconomic indicators are insufficient as development must also involve social indicators including: rising living standard, education indexes, life expectancy, literary rate, health, material prosperity, and poverty reduction. For this reason, development should be understood as a multi-dimensional concept.

\section{Authoritarianism and Economic Development}

As mentioned above, Southeast Asia is the most diverse region. Thus, implications for its governance are different from those in the West that stress the so-called "liberal democracy". Some authors of the Democracy Advantage reject a "development first, democracy later" approach because they argue that "Democracy often flourishes in poor countries...", and that "A democracy-centered development strategy presupposes not only that poor countries can successfully democratize but also that democracy brings political checks and balances, responsiveness to citizen priorities, openness, and self-correcting mechanisms..." (Siegle, Weinstein, \& Halperin, 2004). However, based on the lessons of the Southeast Asian nations, this type of governance cannot survive. Instead, leadership - authoritarianism - to bring about social and political stability required for economic growth has proved to be successful. This is vital to such late developers as Southeast Asian developing countries because authoritarian regimes can, on the one hand, ensure public order and stability, promote a development strategy, select and protect export industries, as well as ensure investor confidence, and suppress other negative factors, like the power of vested interests that hammers or impedes the development process, on the other. This is 
becoming more rational in a sense that Southeast Asia is the most geographically, culturally, and religiously diverse region, and a majority of its population still lives under poverty line.

As such, many ASEAN (Association of Southeast Asian Nations) members under authoritarian regimes, including Indonesia under Suharto's authoritarian regime, Vietnam, Cambodia, Malaysia, and Singapore, have achieved rapid economic growth for over the last quarter century. As in the case of Indonesia, under the leadership of President Sukarno (1945-1966), Indonesia suffered from economic and political instability as a consequence of the so-called "guided democracy" which was declared by Sukarno in July 1957. This did not only stagnate economic situation, but also led to deadlock between those who wanted Indonesia to be an Islamic state, and those who supported the idea of the state based on the Panca Sila ideology—division between Muslims and the Panca Sila groups, the "guided democracy" eventually resulted in economic and political crises in 1965. By 1965 , inflation was $650 \%$ annually, Sukarno's regime left the country with a debt of US\$ two billion and the $900 \%$ increase in the price of rice. This led many observers to term Indonesia under Sukarno's rule a "basket case”. By contrast, after Sukarno's downfall, under authoritarian governance of Major General Suharto (1966-1998), Indonesia managed to escape from the extremely high inflation rate of around $500 \%$ and attained high economic growth with increasing FDI (Foreign Direct Investment) until the eve of his regime's collapse. Per capita income was only virtually US\$ 100 in the early 1960s, but increased rapidly in 1970 and 1980 with US\$ 260 and over US\$ 500 respectively, and in 1996, it reached at US\$1,100, twice that of India, and three times that of Bangladesh. GDP (Gross Domestic Product) growth also appeared rather impressive, particularly steadily increased by $8.8 \%$ in the years 1991-1995. It is apparent that unlike Sukarno, Suharto was able to make a significant progress over the three decades (1967-1996) in terms of impressive economic growth and integrating ethnically diverse people into a nation under a unitary political system. This turned out to be the "golden era" of Indonesia's modern economic history. For this reason, Indonesians called Suharto "the father of development".

In similar fashion, it is not surprising to see the achievement of the authoritarian regime of Vietnam, where impressive economic growth has been steadily achieved since the 1990s. In pre-Doi Moi (Renovation) period, because of economic stagnation, particularly in the early years of unification of Vietnam, there was an increasing pluralist tendency in various parts of the country, especially in rural areas where the Communist Party had put its strong hand for a long time, and in the South where people were familiar with capitalist economy. However, in such a situation, the Party still maintained its strong authoritarian rule and attached importance to measures for economic development as an immediate priority. As a result, Doi Moi (Renovation) - a change from central-planning economy to market-oriented economy - was promulgated at 6th Party Congress in December 1986. Since the 1990s, Vietnam has achieved impressive economic growth and maintained social and political stability. Poverty level was reduced from $58 \%$ in 1993 to $35 \%$ in 2008 . Impressive GDP growth was attained substantially from 1990 to 2008 with GDP annual average growth reaching $7.2 \%$, while FDI inflow was only US\$ 0.2 billion in 1990, but rocketed up to US\$21 billion in 2007-the year of Vietnam's integration in WTO (World Trade Organization), and FDI inflow increased three-fold one year afterwards. In addition, export-led growth, exports of textiles and garments have soared. Thus, Vietnam is now seen as one of the safest markets to attract foreign investors for its further economic development. All of these indicators imply that the authoritarian leadership of the Party has played a decisive role in maintaining social and political stability through economic development first.

Another striking example can be taken from the experience of Cambodia. Only until 1993 when the United Nations held an election, did democracy return to Cambodia. However, the legitimacy of such a fragile coalition 
government headed by co-prime ministers Prince Norodom Ranariddh and Hun Sen was eventually deadlocked by the military coup in July 1997. One decade after the coup, under a dominant party system led by Hun Sen, Cambodia has enjoyed stable economic conditions with strong economic growth. Cambodia's average economic growth rate since 1999 is at 9.5\%, among the highest in Asia (Um, 2008, p. 110), and there was a substantial decrease in the number of people under the poverty line. According to the World Bank 2007, the poverty rate in Cambodia decreased from $47 \%$ in 1994 to $35 \%$ in 2004. It should be noted that political leadership is, as argued above, the first element to bring about economic development before democracy promotion. However, the fact that the mentioned authoritarian regimes have achieved economic development is apparently due to the developmental-minded leadership. In other words, authoritarianism without developmental mindset, e.g. isolation, will make its country lag far behind others with regard to economic development.

Myanmar can be seen as a case in point. Under Ne Win's rule (1962-1988), Burma underwent the so-called the "Burmese way to socialism" and isolation. Since the collapse of Ne Win, Myanmar has entered its two decades of direct military rule, whose power appears undiminished. Because of denial of significant investment in the sectors other than energy and any meaningful foreign economic assistance, in addition to foreign economic sanctions because of political instability, poor infrastructure and primitive financial system, etc., the military has made Myanmar and its people the poorest of Southeast Asia. GDP growth over the years 1990-1999 was virtually $6 \%$, but plummeted to $2.4 \%, 2.5 \%$, and $0.1 \%$ during $2006-2008$ respectively, and $30 \%$ of population still lives under poverty line. Thus, Myanmar remains a very basic agricultural and poor economy with oil and gas revenue to support the regime because regime survival is the highest priority.

Based on the lessons of the above countries, it can be said that "economic development first, democracy later" approach proves to be successful and rational. In other words, the viewpoint that "democracy often flourishes in poor countries..." (Siegle et al., 2004) is a unilateral argument, not looking closely at the Southeast Asian region's diversity in which high percentage of its population still lives under the trap of poverty. According to the Asian Development Bank 2007, in the early 1990s, there were about 39\% below the poverty line in Cambodia, 45\% in the Lao People's Democratic Republic, 15\% in Indonesia, 17\% in Malaysia, 45\% in the Philippines, $58 \%$ in Vietnam, and $27 \%$ in Thailand. In addition, in the early 2000s, there were still around 35\% below the poverty line in Cambodia, $18 \%$ in Indonesia, 33\% in the Philippines, and $29 \%$ in Vietnam. It is apparent that in such a situation, promoting democracy rather than economic development could hammer and impede development, and even lead to turmoil or mismanagement of governance. As in the case of the Philippines, GDP per capita in 1950 stayed in the fourth position in Asia after Singapore, Hong Kong, and Japan, and moved towards "take-off" stage in the 1950s. However, the Philippines' economic development has eventually trailed other ASEAN countries (ASEAN five). Reason for this economic stagnation lies in the fact that the Philippines developed democracy so early. Despite somewhat economic recovery in recent years, the Philippines has remained no credible economic strategy or industrial development program and is governed by an elite oligarchy which uses democracy to defend its vested interests. All implications for the Philippines could therefore be explained as a legacy of early democracy waves without the preconditions. The similar situation can be seen in Thailand where former Prime Minister Thaksin's pluralist and populist policies to open democracy led to the current turmoil, as well as political and economic crisis.

\section{Economic Governance and Democratization}

It is worth noting that political leadership to bring about economic development only serves as the first 
stage in the development process. When economic growth is attained, authoritarianism should be a transitory period and is transformed by the development it promotes because in parallel with economic development is the creation of middle class with rising educational level and literacy, thus in turn raises demand for pluralism and freedom for self-expression. In addition, economic development puts pressure on political leaders to move to the next stage with an increase in new demands (Siegle et al., 2004, p. 62). For this reason, authoritarian system needs to make changes, otherwise an excessively rigid system will, on the one hand, interrupt or prevent further development, as well as serve the interests of a ruling group and will, on the other hand, fail to meet domestic aspiration of people, which may result in strikes and political protests. However, it should also be noted that democratization without corresponding development of governance institutions will bring development failure, and corruption. Thus, to accomplish this goal, it is vital to require effective bureaucratic capacity and institutions, rules and norms, transparency, and accountability. However, democratization needs taking gradual steps to adapt or adjust, instead of quickly pushing it towards democratic governance because Southeast Asia is different from others in the developing world in terms of its diversity; otherwise it may in turn impede or stagnate economic development, as is the case of Indonesia in post-Suharto governance. These are really challenging implications for governance. Vietnam is seen as a case of successful first stage development because of its impressive economic growth, as well as poverty reduction, and it is now considered a safe country for business. However, Vietnam is required to have effective institutions, liberalizing the system by further encouraging the private sector and dealing with corruption. Although the Enterprise Law was promulgated in 2000, however in practice, incentives for the private sector's further development have been slowly implemented, and equalization policy of SOEs (state-owned enterprises) remains slow (Schaumburg-Müller, 2005, p. 352). Indeed, incentives for the development of the private sector will not only promote further economic development, reduce unemployment and poverty, but also give more economic freedom to investors and entrepreneurs and foster transparency and accountability in Vietnam. Cambodia is also another case in point. Despite impressive economic achievement after one decade of the military coup in 1997, Cambodia is still agriculture-based economy (39\%), heavily depending on oil wealth; $26 \%$ of its GDP is from foreign aid, and $35 \%$ of population still lives below the poverty line. According to the World Bank, progress on key aspects of governance, namely the strengthening of critical institutions, and enhancement of transparency, accountability, and the rule of law, remains glacially slow (Um, 2008, p. 112). In addition, corruption remains a big problem that not only impedes effective implementation of policies and critical reforms, but also adds more disparity to classes. For this reason, Cambodia needs to make changes by focusing on the development of manufacturing sector, attaching more importance to educational investment, strengthening financial system, and countering corruption. If Cambodian authoritarianism fails to make changes, and continues to run its economy with heavy reliance upon gas and oil, Cambodia could become another Myanmar in the future.

Through the analysis above, it can be said that when further economic development is achieved as a result of transitory period, it will be the right time for democracy promotion. Viewed from this perspective, Singapore is considered an exception. Although Singapore has enjoyed fully economic development for a long time, it maintains non-democratic governance. Reasons lie in the fact that unlike other ASEAN countries, Singapore is a company whose business is development and wealth creation (Inglehart \& Welzel, 2009). However, it is of the greatest importance that Singapore has successful key aspects of governance, including successful developmental leadership, efficient economic bureaucracy, elimination of corruption, non-corrupt commercial 
judiciary, and excellent strategy to organise a political and economic system rationally in order to maximize prosperity (Inglehart \& Welzel, 2009). This is why Singapore, despite non-democratic governance, remains a safe and attractive country for business of multinational corporations (MNCs). Singaporean FDI inflow increased from US\$ 14 billions in 1997 to US\$ 24 billions one decade later, standing as number-one FDI recipient in the region, and its people are enjoying the highest standard of living in Asia. However, Singapore is facing many problems, particularly it is known as a production base for MNCs because MNCs account for $42 \%$ of GDP, and heavily relies upon external $\mathrm{R} \& \mathrm{D}$, creativity and talent, while indigenous enterprise is weak (Inglehart \& Welzel, 2009). Thus, this Asian "Tiger" or "Lion" is also required to make changes to bring democracy, as well as promote future economic growth by creating greater free speech and pluralism, encouraging local talent and entrepreneurs, and creating genuine participation and governing institutions. Without changes, Singapore is likely to suffer much vulnerability when economic crisis occurs because of its heavy reliance on MNCs, and to have difficulties competing with other regional economies and China. Indeed, Singapore's economic downturn since 2004, with economic growth $-2.0 \%, 2.2 \%, 1.1 \%, 5.5 \%$, and $-10 \%$ predicted in 2009 respectively, suggests that it is time for changes to be made by Singaporean authoritarian regime.

\section{Conclusions}

To conclude, in the development process, the authoritarianism of a number of Southeast Asian countries is apparently the first and decisive element to bring about economic development. In other words, "economic development first, democracy later" is apparently a rational and suitable approach to this diverse region. The successful authoritarian regimes experiencing economic growth can be seen in Indonesia under Suharto's rule, Vietnam, Malaysia, Cambodia, and Singapore, as well as Brunei. However, authoritarianism is required to have developmental-minded leadership as the first priority; otherwise its economy will lag far behind others, as is the case of Myanmar. When economic growth reaches a certain level, and living standard increases with the creation of increasing educational level and self-expression of middle class, there should be a transitory period to move to the next step for further development. However, democratization to address this pressure needs taking time to gradually adapt. If democracy is early or quickly promoted, it could impede development, and even lead to mismanagement or turmoil. This situation can be seen in the Philippines' economic stagnation for a long time as a consequence of early democracy promotion, or in Thailand's economic and political crisis under Thaksin's pluralist and populist policies, or in Indonesia's economic downturn as a consequence of fast democracy promotion after Suharto's collapse in 1998. By contrast, if authoritarian regimes fail to make changes, it is likely to not only impede or interrupt economic development, but also weaken the democratic aspiration of people and possibly lead to the collapse of regime. This is why authoritarianism is required to make changes for further economic development. And when further economic growth is achieved, it is the right time for democracy promotion. This is truly the real meaning of the relationship between good governance and development.

\section{References}

Al-jurf, S. (2010). Good governance \& transparency: Their impacts on development. Retrieved from http://www.uiowa.edu/ ifdebook/ebook2/contents/part2-V.shtml

Asian Development Bank. (1999). Governance in Asia: From crisis to opportunity. Retrieved from http://www.adb.org/ documents/adb-annual-report-1999 
Asian Development Bank. (2008). Asian Development Bank annual report 2007. Retrieved from http://www.adb.org/documents/ adb-annual-report-2007

Inglehart, R., \& Welzel, C. (2009). How development leads to democracy: What do we know about modernization today? Foreign Affair, 88(2), 33-48.

Lawal, G., \& Tobi, A. (2006). Bureaucratic corruption, good governance and development: The challenges and prospects of institution building in Nigeria. Journal of Applied Sciences Research, 2(10), 642-649.

Schaumburg-Müller, H. (2005). Private-Sector development in a transition economy: The case of Vietnam. Development in Practice, 15(3-4), 349-361.

Siegle, J. T., Weinstein, M. M., \& Halperin, M. H. (2004). Why democracies excel. Foreign Affairs, 83(5), 57-71.

Um, K. (2008). Cambodia: A decade after the coup. Southeast Asian Affairs. Singapore: Institute of Southeast Asian Studies. Pp. 109-119.

Weatherbee, D. E. (2004). Governance in Southeast Asia: The good, the bad, and the ugly. In Y. Sato (Ed.), Growth and governance in Asia (pp. 179-192). Asia-Pacific Center for Security Studies.

World Bank Group. (2006). The world development report 2007: Development and the next generation. Washington D.C.: The World Bank. Retrieved from http://documents.worldbank.org/curated/en/556251468128407787/pdf/359990WDR0complete. pdf 